\title{
Polyploid races, genetic structure and morphological features of the earthworm Octodrilus transpadanus (Rosa, 1884) (Oligohaeta: Lumbricidae) in the Ukraine
}

\author{
A.V. Garbar ${ }^{1}$, I.P. Onyschuk ${ }^{1}$, S.V. Mezhzherin ${ }^{2}$ \\ ${ }^{1}$ Ivan Franko Zhytomyr State University, Velika Berdychevska 40, Zhytomyr 10008, \\ Ukraine. ${ }^{2}$ Dep. Evol. Genet. Basis of Systematics. Schmalhausen Institute of Zoology \\ NAS of Ukraine, B. Khmelnytskogo 15, Kiev 01601, Ukraine. \\ E-mails: ${ }^{1}$ saguaroklub@mail.ru, ${ }^{2}$ mezh@izan.kiev.ua
}

\begin{abstract}
Kariological investigation of the earthworm Octodrilus transpadanus (Rosa, 1884) in the Ukraine showed that this species is represented by at least three races of different ploidy with the basic chromosome number $n=15$. Strict geographic heterogeneity of electrophoretic spectra of different populations was registered: south-eastern populations $(7 \mathrm{n}=105)$ are characterized by a clonal structure, whereas western (from $3 n=45$ to $4 n=60)$ and south-western $(2 n=30)$ ones have a high level of polymorphism. The Crimea sample $(4 n=60)$ is well isolated, has no clonal structure and is characterized by a series of specific alleles, which are absent in forms from continental Ukraine. All the forms turned out to be well isolated morphologically, except for the clonal forms, which are very much alike.
\end{abstract}

Key words: earthworms, Octolasion, Octodrilus, polyploidy, genetic structure, morphology.

\section{INTRODUCTION}

The Mediterranean species Octodrilus transpadanus (Rosa, 1884) is widely distributed in the east and the south of the Ukraine (Zrazhevsky, 1957; Perel, 1979; Buslenko, 2005). It is a moisture-loving species which lives deep in the soil and prefers grey forest soils, meadow-steppe and common black soils.

At present there are different views on the genus affiliation of this species. For a long time it was ascribed to the genus Octolasion Orley, 1885. Later, on the basis of new taxonomic features (the presence of diverticula in the 10th segment, the quantity of spermathecae and chromosome numbers) P. Omodeo suggested the division of this genus into two subgenera: Octolasion (Incolore) and Octolasion (Purpureum) (Omodeo, 1952). Later he renamed Octolasion (Purpureum) into Octodrilus (Omodeo, 1956). Bouché (1972) promoted subgenus Octodrilus to the rank of genus and included in it Octodrilus transpadanus. As a result of one of the last revisions of the Lumbricidae (Christian, Zicsi, 1999) one more genus Octodriloides Zicsi, 1986, was separated from the genus Octodrilus. O. transpadanus remained in the latter one.

It is necessary to note that this initiative was not supported by all researchers. T.S. 
Vsevolodova-Perel (1997) holds to the broader concept of Octolasion genus, combining all species of three mentioned above genera into one genus on the basis of the same form and orientation of the nephridial bladders. According to this point of view $O$. transpadanus belongs to the genus Octolasion.

The first karyological investigation of $O$. transpadanus was made in Italy (Omodeo, 1952). It was established that earthworms of this genus are represented in Italy by the diploid race $(\mathrm{n}=18)$ (Omodeo, 1952) and reproduce by amphimixis. Later the chromosome number was defined more precisely. As it turned out, the haploid set of $O$. transpadanus consists not of 18 but of 15 elements (Omodeo, 1962). Earthworms of this species from other populations had the same haploid chromosome number $(n=15,2 n=30)$ (Bakhtadze, 2008; Omodeo, 1962; Casellato, 1987; Vedovini, 1973). Thus, according to published data, all specimens of $O$. transpadanus were diploid.

At present the genetic structure of populations of many Lumbricid species is rather well investigated (Terhivuo, Saura, 2006; Vlasenko et al., 2007; Mezhzherin et al., 2008). However, researchers have been interested basically in study of polyploid complexes, which are characterized by the clonal structure of populations. As $O$. transpadanus is considered a classical diploid, populational and genetical studies of this species have not been conducted previously.

In the Ukraine $O$. transpadanus has been found repeatedly (Zrazhevsky, 1957; Perel, 1979), but karyological investigations have not been conducted. The purpose of this work is to describe the karyotypes and perform comparative analysis of chromosome sets of $O$. transpadanus from different parts of the Ukraine.

\section{MATERIAL AND METHODS}

The material for this study was collected in the spring-autumn period of 2005-2008 using generally accepted methods (Byzova et al., 1987). 9 samples from the Ukraine have been investigated (Vylkove town, Odessa region; Dnipropetrovsk city; Nastasivka village, Dnipropetrovsk region; Kotelva village, Poltava region; Mostove village, the Crimea; Novostanichnoe village, Lugansk region; Kalnyk village, Kincses village, and Irlava village, Zakarpats'ka region).

79 specimens, identified as $O$. transpadanus according to tables of Perel (1979) and Vsevolodova-Perel (1997), were used for karyological investigations. Preparations for the analysis were made from 32 specimens.

Karyological preparations were made from seminal vesicles with methods previously used in Lumbricidae investigations (Garbar, Onyschuk, 2007; Garbar, Vlasenko, 2007). The earthworms were injected with $0.1 \%$ colchicine 19 hours before the dissection.

The spermatocytes were placed for $50 \mathrm{~min}$ utes in distilled water and fixed in the 1:3 mixture of glacial acetic acid and ethanol. Chromosome preparations were obtained by the reprint method (Sitnikova et al., 1990). Dried preparations were stained with Romanovsky type stain in $0.01 \mathrm{M}$ phosphate buffer $(\mathrm{pH}$ 6.8)). The preparations were analysed with a «Mikmed» microscope (10x90).

Electrophoretic variability of spectra of enzymes (aspartate aminotransferase (AST), malate dehydrogenase (MDH), nonspecific esterases (ES) and superoxide dismutase (SOD) in extracts from a caudal part of body was investigated by the method of PAG-electrophoresis in Tris-EDTA-borate buffer system (Peacock et al., 1965) .

Morphological investigations were conducted on fixed worms. Length of whole body (L), forward end of body $\left(1_{1}\right)$, clitellum $\left(l_{2}\right)$, 


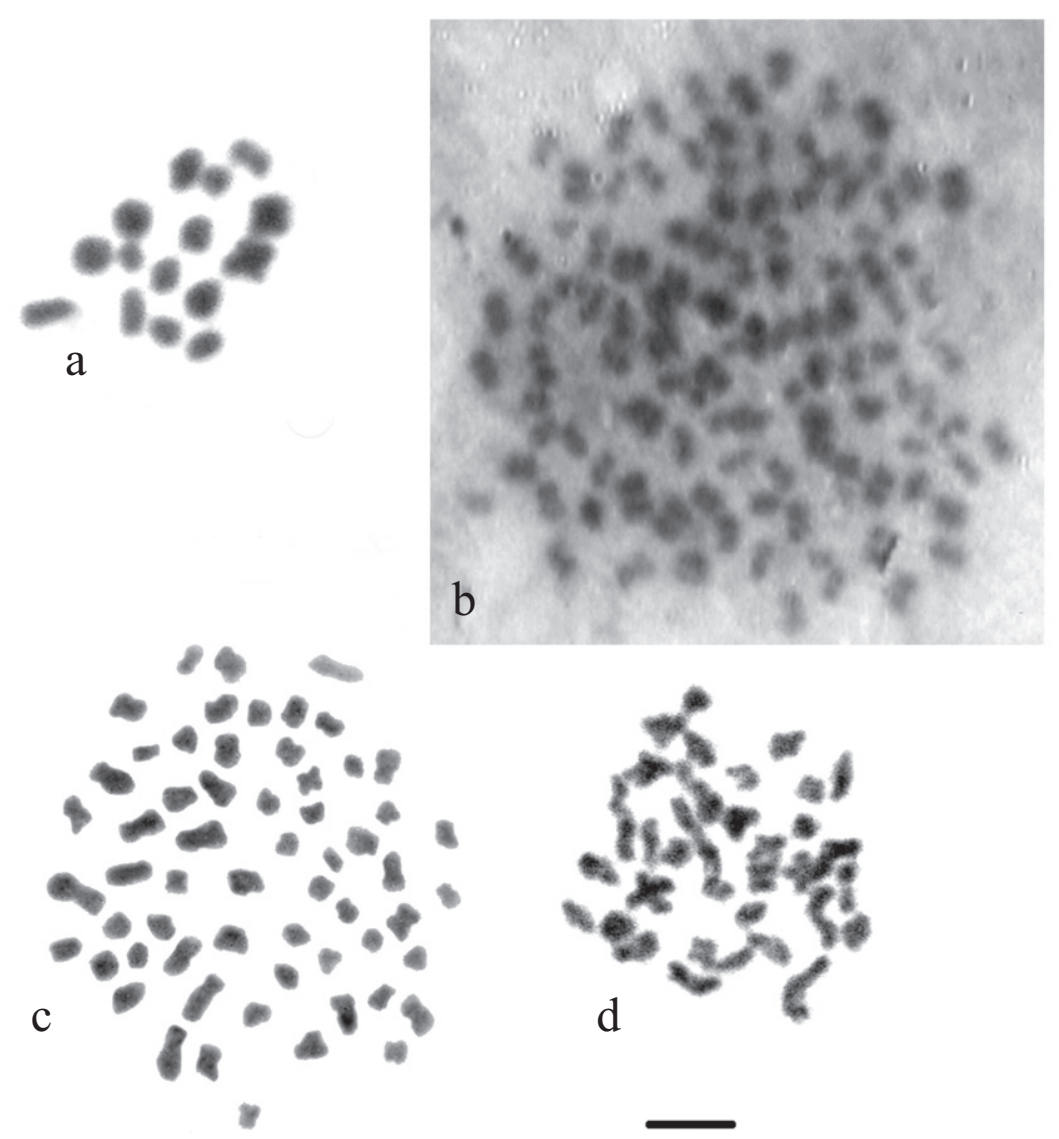

Fig. 1. The chromosomes of $O$. transpadanus. a - the diakinesis of diploid specimen from Vylkove $(\mathrm{n}=15)$. b - mitotic metaphase of heptaploid specimen from Dnipropetrovsk $(7 \mathrm{n} \approx 105)$. c - mitotic metaphase of tetraploid specimen from Kalnyk $(2 n=60)$. $\mathbf{d}$ - diakinesis of tetraploid specimen from Kalnyk. $2 \mathrm{n}=10 \mu \mathrm{m}$.

and the maximal diameter of a body behind clittelum (d) were measured. Total number of segments $\left(\mathrm{n}_{1}\right)$ and number of segments up to clitellum $\left(n_{2}\right)$ were counted. The size and position of the clitellum, the form and position of pubertate platens, the form of the head blade, distance between setae, position of spinal pores and papillae were defined. The average length of one segment $\left(\mathrm{L} / \mathrm{n}_{1}\right)$ and the average length of one segment up to clitellum $\left(1_{1} / n_{2}\right)$ were calculated and the number of indices, describing the relative sizes of a body, was counted.

Statistical processing of obtained data was carried out by means of a package of applied statistical programs STATISTICA 6.0.

\section{RESULTS AND DISCUSSION}

\section{Karyological analysis}

Vylkove town, Odessa region. All investigated specimens of $O$. transpadanus from this population turned out to be diploid $(2 n=30)$. At the stage of spermatogonial meiosis 15 bivalents were registered (Table 1 and Fig. 1, a).

Dnipropetrovsk city. The chromosome number of earthworms from this sample was established approximately. The chromosome number in the mitotic metaphase exceeded 
Table 1. Chromosome numbers of earthworms $O$. transpadanus.

\begin{tabular}{|c|c|c|c|c|c|c|}
\hline \multirow{3}{*}{ Biotype } & \multicolumn{3}{|c|}{ Mitosis } & \multicolumn{3}{|c|}{ Meiosis } \\
\hline & \multicolumn{2}{|c|}{ Number of } & \multirow{2}{*}{$\begin{array}{l}\text { Karyotype } \\
\text { (2n) }\end{array}$} & \multicolumn{2}{|c|}{ Number of } & \multirow{2}{*}{$\begin{array}{l}\text { Karyotype } \\
\text { (n) }\end{array}$} \\
\hline & Plates & $\begin{array}{l}\text { Indivi- } \\
\text { duals }\end{array}$ & & Plates & $\begin{array}{l}\text { Indivi- } \\
\text { duals }\end{array}$ & \\
\hline \multirow{5}{*}{ Dnipropetrovsk } & 14 & 6 & 105 & 4 & 4 & 47 \\
\hline & 3 & 1 & 106-108 & & & \\
\hline & 3 & 2 & 108 & 5 & 3 & 58 \\
\hline & 2 & 1 & 112 & 1 & 1 & 63 \\
\hline & 2 & 1 & 118 & 4 & 2 & 45 \\
\hline \multirow{2}{*}{ Mostove } & 14 & 2 & 60 & 2 & 1 & 27 \\
\hline & & & & 3 & 1 & 28 \\
\hline \multirow{3}{*}{ Kalnyk } & 8 & 2 & 45 & 1 & 1 & 26 \\
\hline & 24 & 4 & 60 & 3 & 2 & 27 \\
\hline & 2 & 1 & 68 & 9 & 4 & 32 \\
\hline \multirow{3}{*}{ Vylkove } & 5 & 2 & 28 & 7 & 3 & 14 \\
\hline & 10 & 7 & 30 & 30 & 7 & 15 \\
\hline & & & & 5 & 2 & 16 \\
\hline
\end{tabular}

100. These specimens probably had 7 fold level of chromosome set ploidy (7n) with the basic chromosome number $n=15$ (Table 1, Fig. $1, b)$.

Kalnyk village, Zakarpats'ka region. Worms from this sample have the number of chromosomes in mitotic metaphase that varied from 45 up to 60 (Table 1, Fig. 1, c, 1, d). It is possible that in this population we observe coexisting triploid and tetraploid races.

Mostove village, the Crimea. Specimens of $O$. transpadanus from this collection site turned out to be tetraploid with the basic chromosome number $\mathrm{n}=15$. Their mitotic metaphases had 60 two-armed chromosomes $(\mathrm{FN}=120)$ (Fig. 1, c). At the stage of diakinesis in spermatogonial meiosis the number of elements varied but always exceeded the haploid number. In addition to that the plates always had polyvalents (Table 1, Fig. 2).

The obtained data prove that in the Ukraine $O$. transpadanus is represented by a series of races with different level of ploidy. According to published information it is a diploid amphimictic species in Italy, France, and Georgia (Omodeo, 1962; Casellato, 1972; Vedovini, 1973; Bakhtadze 2008). In the investigated Ukrainian localities we discovered four forms of $O$. transpadanus with different ploidy levels: diploid $(2 n=30)$, triploid $(3 n=45)$, tetrapoloid $(4 n=60)$ and, perhaps, heptaploid $(7 n>100)$. The presence of both unpaired and paired ploidy forms testifies to the hybrid nature of polyploidy in O. transpadanus. This view is supported by the character of meiosis in polyploids (variable number of polyvalents, unstable number of elements) (Fig. 1, d).

Numerous changes observed in the meio- 


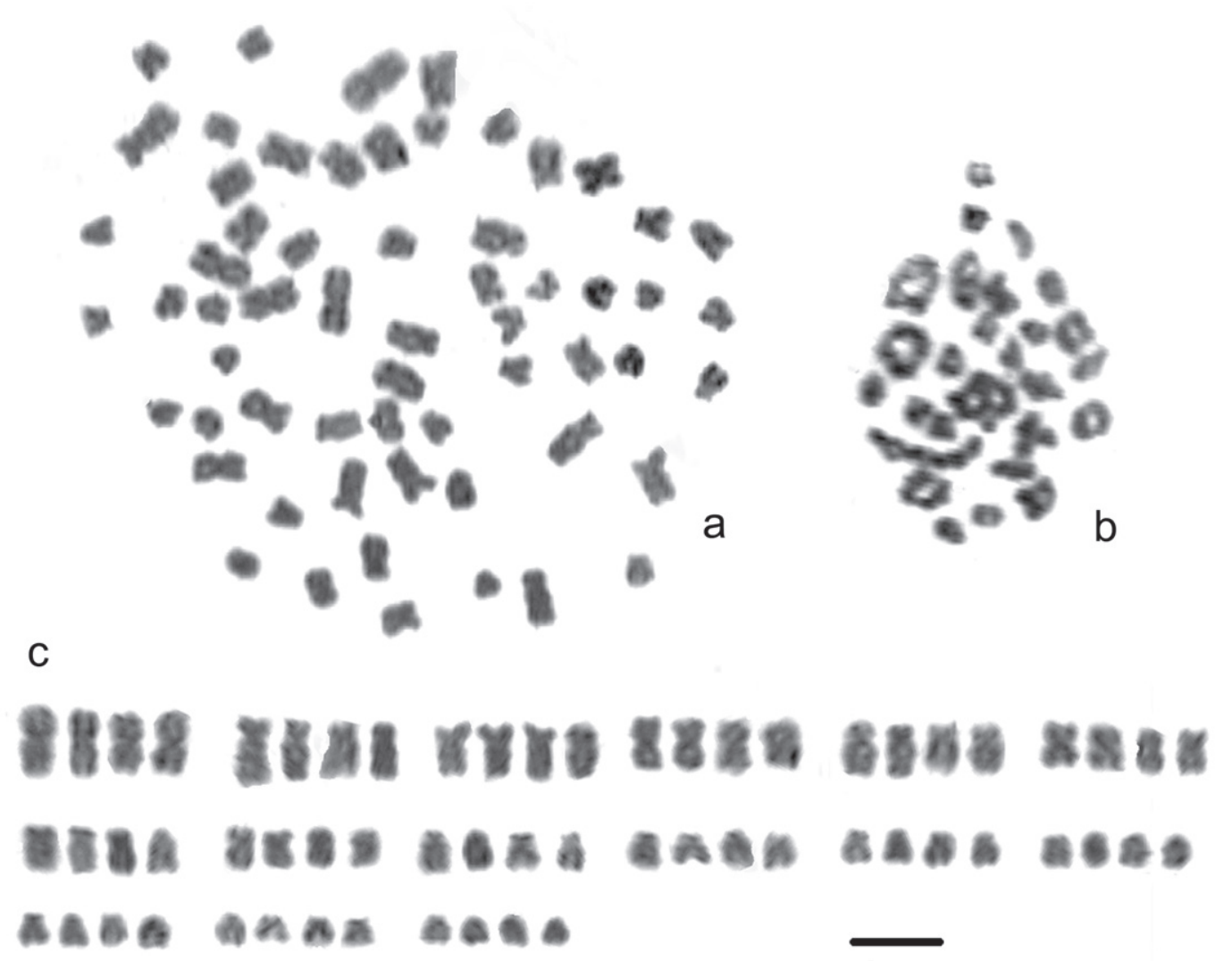

Fig. 2. The chromosomes of tetraploid O. transpadanus $(4 \mathrm{n}=60)$ from Mostove village (the Crimea). a - mitosis metaphase. $\mathbf{b}$ - diakinesis. $\mathbf{c}$ - karyogram. $2 \mathrm{n}=10 \mu \mathrm{m}$.

sis in polyploid races probably testify the occurrence of reproduction by apomixis, which is typical for polyploid races of earthworms.

Diploid races with normal spermatogonial meiosis reproduce by amphimixis (Omodeo, 1962; Casellato, 1972; Vedovini, 1973).

\section{Biochemical gene marking}

To investigate the genetic structure of $O$. transpadanus populations the variability at four enzyme systems that generate reliable and reproducible results in electrophoresis conditions (Peacock et all., 1965) was studied: aspartate aminotrasferase (AST), superoxyde dismutase (SOD), malate dehydrogenase
(MDH) and non-specific esterases (ES), coded with a series of loci. The last two enzymes were variable.

Comparison of the variability of electrophoretic spectra of different populations have shown a distinct geographic heterogeneity: the south-eastern populations have a clonal structure, whereas the western and south-western ones are polymorphic (Table 3 and Fig. 3).

In the first group two main forms differing in MDH spectra were identified. An electromorph, corresponding to conventional MdhB genotype, is fixed in one group and $\mathrm{MdhAB}$ heterozygote is presumed to be fixed in the other. Clone specimens of MdhB electropho- 
Table 2. The distribution of malate dehydrogenase electromorph in populations of $O$. transpadanus from the territory of the Ukraine.

\begin{tabular}{|c|c|c|c|c|c|c|c|c|c|}
\hline $\begin{array}{c}\text { Electro- } \\
\text { morph }\end{array}$ & $\begin{array}{c}\text { Dnipro- } \\
\text { petrovsk }\end{array}$ & $\begin{array}{c}\text { Nasta- } \\
\text { sivka }\end{array}$ & Kotelva & $\begin{array}{c}\text { Novo- } \\
\text { stanichne }\end{array}$ & Mostove & Vylkove & Kalnic & Kinchesh & Irlava \\
\hline B & 6 & & 3 & & & 21 & & 2 & \\
\hline $\mathrm{ABB}$ & & & & & & 2 & 4 & 17 & 20 \\
\hline $\mathrm{AB}$ & 6 & 8 & & 2 & & & 3 & 5 & 6 \\
\hline $\mathrm{AAB}$ & & & & & & & 2 & 3 & 3 \\
\hline $\mathrm{A}$ & & & & & & & 1 & 4 & 8 \\
\hline A"AA & & & & & 1 & & & & \\
\hline A"AAB & & & & & 2 & & & & \\
\hline
\end{tabular}

Table 3. Diversity of genotypes in populations of O. transpadanus from the territory of the Ukraine.

\begin{tabular}{|l|c|c|}
\hline Location & $\begin{array}{c}\text { Number of } \\
\text { individuals }\end{array}$ & $\begin{array}{c}\text { Number of } \\
\text { genotypes }\end{array}$ \\
\hline Dnipropetrovsk & 12 & 4 \\
\hline Irlava & 37 & 8 \\
\hline Kalnic & 10 & 9 \\
\hline Kinchesh & 31 & 6 \\
\hline Mostove & 3 & 3 \\
\hline Novostanichne & 2 & 1 \\
\hline Vylkove & 23 & 13 \\
\hline Kotelva & 3 & 1 \\
\hline Nastasivka & 8 & 2 \\
\hline
\end{tabular}

retic type were found in Dnipropetrovsk (6 individuals) and Poltava region (Kotelva village, 3 individuals), also the latter have peculiar alleles in Es-6 locus. Specimens of an alternative clone with MdhAB electrophoretic type were found in Dnipropetrovsk (5 individuals), Dnipropetrovsk region (Nastasivka village, 6 individuals) and Lugansk region (Novostanichnoye village, 2 individuals).

Unlike south-eastern $O$. transpadanus populations, the western and south-western ones are not only more numerous, which is reflected in the higher number of investigated samples, but also characterized by an excep- tionally high level of genetic polymorphism. The variability of non-specific esterase loci in the population from Odessa region (Vylcovo town, 38 individuals) and Transcarpathian region (Kalnik village, 11 individuals; Kinchesh village, 33 individuals; Irlyava village, 41 individuals) was so high that it was virtually impossible to find within a sample two specimens with the identical spectra. Analysis of spectra has shown that there is no clear tendency for equal distribution of homo- and heterozygote genotypes of certain loci, which is characteristic of amphimictic organisms and has been recorded for diploid species of earthworms (Mezhzherin et al., 2008; Stille et al., 1980). The situation resembles the cases of hypervariability in organisms, producing gametes in upset meiosis (Cywinska, Hebert, 2002). As a result, the genetic variability in a population greatly increases and every specimen becomes as unique as if it were a separate clone. A similar case was registered in the parthenogenetic species Aporrectodea rosea (Savigny, 1826) with different levels of ploidy, populations of which have either a strict clonal structure (Vlasenko et al., 2007) or are an aggregate of specimens where each individual has its unique spectrum (Vlasenko, 2008).

A peculiar interest is provoked by the $M d h$ 


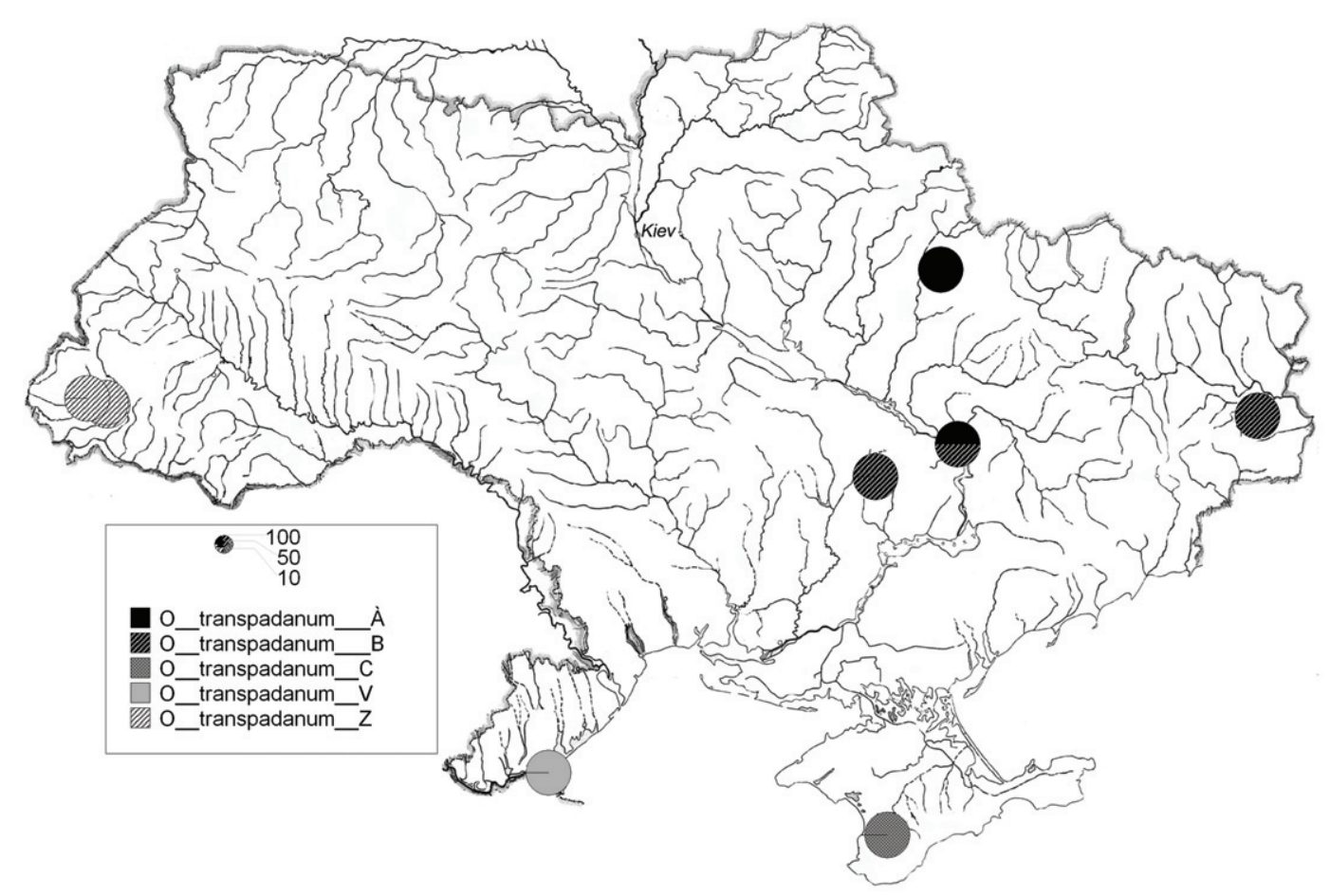

Fig. 3. The distribution of O. transpadanus genetic forms in the Ukraine.

locus, which is weakly variable in the Vylkovo population, but is highly polymorphic in the Zakarpats'ka region. The spectra of this locus are characterized by unbalanced combinations of homo- and heterozygotes, and most heterozygotes show the so-called dose effect (Table 2). An attempt to find a correletion between spectra types of MDH and non-specific esterases for separate specimens was not successful and proved the non-clone character of variability in this population.

The sample from the Crimea (Mostove village, 3 individuals) is different from other $O$. transpadanus populations. It is characterized by polymorphism of spectra of both non-specific esterases and MDH so it doesn't have clone structure but is characterized by a series of specific alleles, absent in continental forms. It is evident that in the Crimea there is either an old divergent form or a form gener- ated with $O$. transpadanus continental forms. From our point of view this is the reason why the Crimean form should be considered as a separate species.

\section{Analysis of morphological peculiarities}

Average values of investigated parameters of $O$. transpadanus genetic forms are given in Table 4. All specimens in general corresponded to the species descriptions (Perel, 1979; Christian, Zicsi, 1999) and were reliably identified by diagnostic characteristics. At the same time the analysis of morphological features has shown reliable differences in genetic forms (Table 5).

The earthworms from the Crimea (form (C.)) turned out to be the most isolated by morphology and reliably differed from all other forms by 8-9 out of 12 used features (Table $5)$. They were also characterized by the high- 
Table 4. Average (M) and standard errors (m) of morphological parameters of different forms of $O$. transpadanus. L - Length of whole body, $1_{1}$ - forward end of body, $1_{2}$ - clitellum, $\mathrm{d}$ - maximal diameter of a body behind clittelum, $\mathrm{n}_{1}$ - total number of segments, $\mathrm{n}_{2}$ - number of segments up to clitellum.

\begin{tabular}{|c|c|c|c|c|c|c|}
\hline \multirow{2}{*}{\multicolumn{2}{|c|}{$\begin{array}{l}\text { Forms } \\
\begin{array}{l}\text { Parameters / Number } \\
\text { of individuals }\end{array}\end{array}$}} & \multirow{3}{*}{\begin{tabular}{c|}
$\mathbf{A}$ \\
$\mathbf{1 1}$ \\
5,20
\end{tabular}} & \multirow{3}{*}{\begin{tabular}{|c|}
$\mathbf{B}$ \\
$\mathbf{1 4}$ \\
5,46
\end{tabular}} & \multirow{3}{*}{$\begin{array}{c}\text { (C.) } \\
\mathbf{3} \\
7,5\end{array}$} & \multirow{3}{*}{$\begin{array}{c}\text { (V.) } \\
49 \\
4,88\end{array}$} & \multirow{3}{*}{$\begin{array}{c}\mathbf{( Z . )} \\
\mathbf{8 5} \\
5,24\end{array}$} \\
\hline & & & & & & \\
\hline \multirow{2}{*}{$\mathrm{D}, \mathrm{MM}$} & $\mathrm{M}$ & & & & & \\
\hline & $\mathrm{m}$ & 0,17 & 0,17 & 0,29 & 0,07 & 0,05 \\
\hline \multirow{2}{*}{$\mathrm{L}, \mathrm{MM}$} & $\mathrm{M}$ & 56,18 & 56,43 & 159,33 & 53,69 & 59,43 \\
\hline & $\mathrm{m}$ & 3,35 & 1,95 & 43,85 & 1,96 & 0,76 \\
\hline \multirow{2}{*}{$1_{1}, \mathrm{MM}$} & $\mathrm{M}$ & 16,54 & 17,67 & 27,00 & 17,12 & 20,51 \\
\hline & $\mathrm{m}$ & 0,50 & 0,56 & 2,51 & 0,48 & 0,21 \\
\hline \multirow{2}{*}{$1_{2}, \mathrm{MM}$} & $\mathrm{M}$ & 5,71 & 5,89 & 11,00 & 5,27 & 4,62 \\
\hline & $\mathrm{m}$ & 0,50 & 0,36 & 0,57 & 0,15 & 0,09 \\
\hline \multirow{2}{*}{$\mathrm{n}_{1}$} & $\mathrm{M}$ & 122,36 & 127,57 & 117,33 & 126,89 & 134,15 \\
\hline & $\mathrm{m}$ & 6,04 & 2,75 & 2,40 & 2,40 & 2,09 \\
\hline \multirow{2}{*}{$\mathrm{L} / \mathrm{n}_{1}$} & $\mathrm{M}$ & 0,46 & 0,44 & 1,35 & 0,37 & 0,45 \\
\hline & $\mathrm{m}$ & 0,02 & 0,02 & 0,36 & 0,37 & 0,44 \\
\hline \multirow{2}{*}{$1_{1} / n_{2}$} & $\mathrm{M}$ & 0,57 & 0,61 & 0,93 & 0,59 & 0,69 \\
\hline & $\mathrm{m}$ & 0,02 & 0,02 & 0,08 & 0,02 & 0,01 \\
\hline \multirow{2}{*}{$\mathrm{D} / \mathrm{L}$} & $\mathrm{M}$ & 9,50 & 9,73 & 5,78 & 9,61 & 8,95 \\
\hline & $\mathrm{m}$ & 0,49 & 0,26 & 1,97 & 0,36 & 0,15 \\
\hline \multirow{2}{*}{$\mathrm{D} / \mathrm{l}_{1}$} & $\mathrm{M}$ & 31,62 & 31,11 & 28,05 & 29,42 & 25,76 \\
\hline & $\mathrm{m}$ & 1,19 & 1,03 & 1,54 & 0,79 & 0,35 \\
\hline \multirow{2}{*}{$1_{1} / \mathrm{L}$} & $\mathrm{M}$ & 30,16 & 31,48 & 20,44 & 32,55 & 34,83 \\
\hline & $\mathrm{m}$ & 1,42 & 0,75 & 6,48 & 0,60 & 0,44 \\
\hline \multirow{2}{*}{$1_{2} / \mathrm{L}$} & $\mathrm{M}$ & 10,11 & 10,42 & 8,41 & 10,19 & 7,91 \\
\hline & $\mathrm{m}$ & 0,67 & 0,47 & 2,74 & 0,35 & 0,22 \\
\hline \multirow{2}{*}{$1_{2} / 1_{1}$} & $\mathrm{M}$ & 34,09 & 33,31 & 41,05 & 31,22 & 22,88 \\
\hline & $\mathrm{m}$ & 2,42 & 1,69 & 1,90 & 0,77 & 0,58 \\
\hline
\end{tabular}

est values of all size characteristics (Table 4).

Genetically polymorphic populations from the Zakarpats'ka region (form (Z.)) and Vylkovo (form (V.)) reliably differed from one another by 10 characteristics. At the same time form (V.) is very close to both clone forms, A and $\mathrm{B}$, as it reliably differs from them by only one characteristic, whereas form (Z.) reliably differed from forms A and B by 7-8 characteristics (Table 5). Significant differences be- tween clone forms were not found.

Analysis of a combined sample of all forms (Table 6) has shown that there is the significant morphological isolation of Crimean earthworms (form (C.)) from all other forms: they are discriminated at $100 \%$ level (Table 6). The discrimination level of forms (V.) and (Z.) is rather high - $80 \%$ and $96 \%$ accordingly. It is necessary to mention that representatives of clone forms are not effectively discriminated 


\section{Euclidean distances}

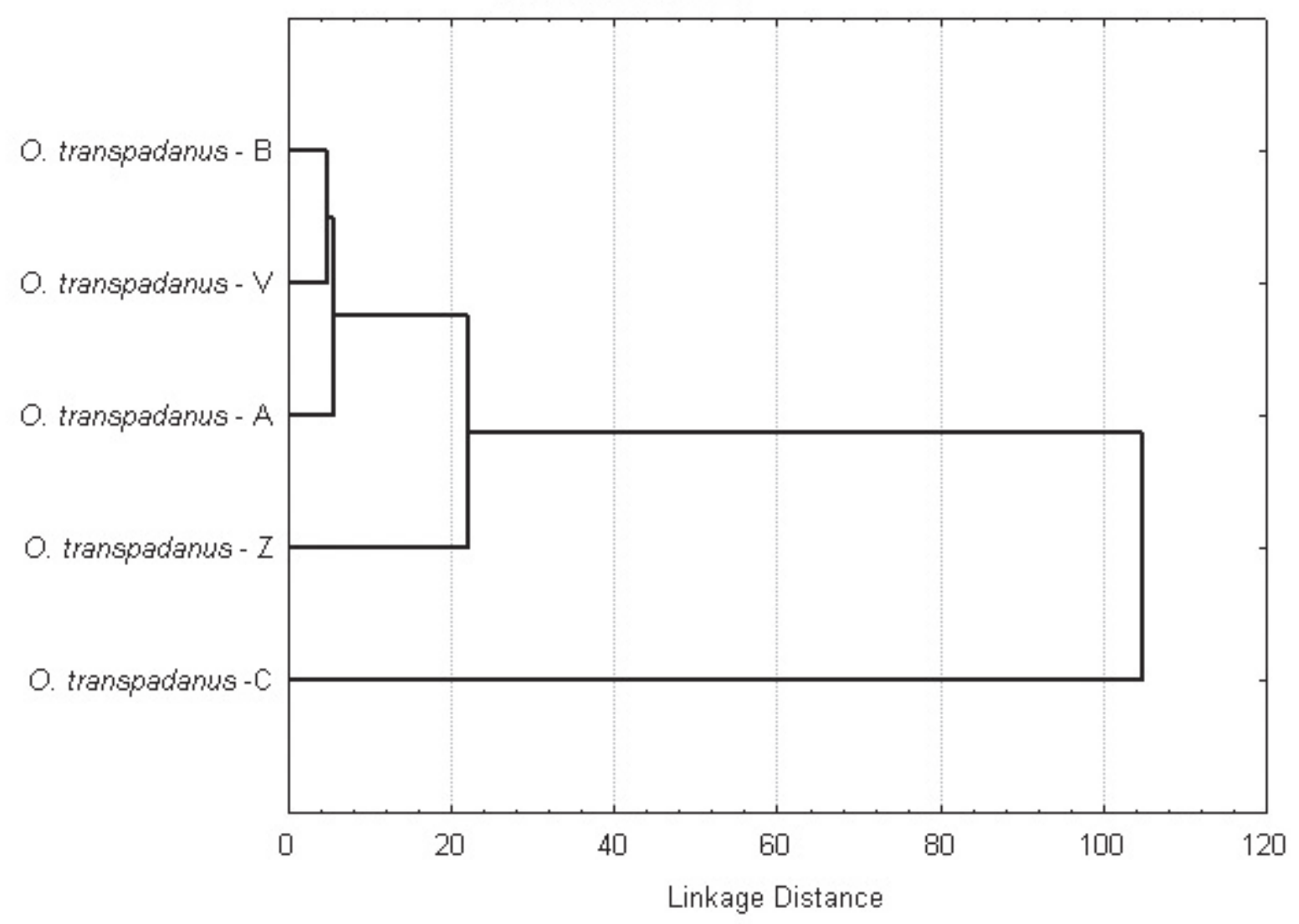

Fig. 4. Tree diagram of dissimilarity for $O$. transpadanus forms on the basis of morphological parameters.

Table 5. Reliable differences in $O$. transpadanus forms for morphological parameters (ANOVA, LSD-test). * $\mathrm{p}<0,05, * * \mathrm{p}<0,01, \mathrm{p}<0,001 * * *$. L - Length of whole body, $1_{1}$ - forward end of body, $1_{2}$ - clitellum, $\mathrm{d}$ - maximal diameter of a body behind clittelum, $\mathrm{n}_{1}$ - total number of segments, $\mathrm{n}_{2}$ - number of segments up to clitellum.

\begin{tabular}{|c|c|c|c|c|c|c|c|c|c|c|c|c|}
\hline Forms & $\begin{array}{c}\mathrm{D} \\
\mathbf{m m}\end{array}$ & $\begin{array}{c}\mathbf{L} \\
\mathbf{m m}\end{array}$ & $\begin{array}{c}\mathrm{l}_{1} \\
\mathrm{~mm}\end{array}$ & $\begin{array}{c}\mathrm{l}_{2} \\
\mathrm{~mm}\end{array}$ & $n_{1}$ & $\mathbf{L} / \mathbf{n}_{1}$ & $\mathrm{l}_{1} / \mathrm{n}_{2}$ & D/L & $\mathrm{D} / \mathrm{l}_{1}$ & $I_{1} / L$ & $l_{2} / L$ & $I_{2} / I_{1}$ \\
\hline \multicolumn{13}{|l|}{$B-A$} \\
\hline B - (C.) & $* * *$ & $* * *$ & $* * *$ & $* * *$ & & $* * *$ & $* * *$ & $* *$ & & $* * *$ & & $*$ \\
\hline B - (V.) & $* *$ & & & & & & & & & & & \\
\hline B - (Z.) & & & $* *$ & $* * *$ & & & $* * *$ & & $* * *$ & $* *$ & $* * *$ & $* * *$ \\
\hline A - (C.) & $* * *$ & $* * *$ & $* * *$ & $* * *$ & & $* * *$ & $* * *$ & $* *$ & & $* * *$ & & \\
\hline $\mathrm{A}-(\mathrm{V})$. & & & & & & $*$ & & & & & & \\
\hline A - (Z.) & & & $* * *$ & $* *$ & $*$ & & $* * *$ & & $* * *$ & $* * *$ & $* *$ & $* * *$ \\
\hline (C.) - (V.) & $* * *$ & $* * *$ & $* * *$ & $* * *$ & & $* * *$ & $* * *$ & $* * *$ & & $* * *$ & & $* *$ \\
\hline (C.) - (Z.) & $* * *$ & $* * *$ & $* * *$ & $* * *$ & & $* * *$ & $* * *$ & $* *$ & & $* * *$ & & $* * *$ \\
\hline (V.) - (Z.) & & * & $* * *$ & $* * *$ & & $* *$ & $* * *$ & $*$ & & $* *$ & $* * *$ & $* * *$ \\
\hline
\end{tabular}


Table 6. The reliability of $O$. transpadanus forms discrimination on morphological parameters in total.

\begin{tabular}{|c|c|c|c|c|c|c|}
\hline Form & $\mathbf{\%}$ & $\mathbf{1}$ & $\mathbf{2}$ & $\mathbf{3}$ & $\mathbf{4}$ & $\mathbf{5}$ \\
\hline A (1) & 45,46 & 5 & 3 & 0 & 3 & 0 \\
\hline B (2) & 42,86 & 0 & 6 & 0 & 7 & 1 \\
\hline (C.) (3) & 100 & 0 & 0 & 3 & 0 & 0 \\
\hline (V.) (4) & 79,59 & 2 & 2 & 0 & 39 & 6 \\
\hline (Z.) (5) & 96,47 & 0 & 0 & 0 & 3 & 82 \\
\hline Total & 83,33 & 7 & 11 & 3 & 52 & 89 \\
\hline
\end{tabular}

but are somewhat isolated from all the others. Cluster analysis of the set of morphological parameters has shown similar results (Fig. 4).

\section{Conclusions}

Karyological investigation of O. transpadanus earthworms in the Ukraine has shown that this species is represented by at least three races of different ploidy with the basic chromosome number $\mathrm{n}=15$.

Strict geographic heterogeneity of electrophoresis spectra of different populations is registered: south-eastern populations $(7 \mathrm{n}=105)$ are characterized with clone structure, whereas western (from $3 n=45$ to $4 n=60$ ) and southwestern $(2 n=30)$ ones have high level of polymorphism. The Crimea sample $(4 n=60)$ is well isolated, has no clonal structure and is characterized by a series of specific alleles, which are absent in forms from continental Ukraine.

All the forms turned out to be well isolated morphologically, except for clonal forms that are very much alike.

\section{REFERENCES}

Bakhtadze N. G., Bakhtadze G. I., Kvavadze E. Sh. 2008. The chromosome numbers of Georgian earthworms (Oligochaeta: Lumbricidae) // Comp. Cytogenet. 2(1): 79-83.

Bouché M. B. 1972. Lombriciens de France. Ecologie et systématique // Ann. Zool. - Écol. Anim. 72(2): 1-671.
Buslenko L. V. 2005. Lumbricids (Oligochaeta: Lumbricidae) as structural element of biocenosis in Volyn woodland region: Abstract of $\mathrm{PhD}$ thesis. Dnepropetrovsk national University, Ministry of Education and Science of Ukraine. Dnipropetrovsk. 20 p. (In Ukrainian).

Byzova U. B., Gilyarov M. S., Dunger V. V. and others. 1987. Quantitative methods in the soil zoology. Nauka. 288 p. (In Russian).

Casellato S. 1987. On Polyploidy in Oligochaetes with particular reference to Lumbricids, (pp.75-87) // Bonvicini Pagliai A.M., Omodeo P. (Eds.). On Earthworms. Sel. Symp. Monogr. U.Z.I., 1987, 2, Mucchi, Modena, Italy.

Christian E., Zicsi A. 1999. Ein synoptischer Bestimmungsschlüssel der Regenwürmer Österreichs (Oligochaeta: Lumbricidae) // Die Bodenkultur. 50: 121-131.

Cywinska A., Hebert P. D. N. 2002. Origins of clonal diversity in the hypervariable asexual ostracode $C y$ prodopsis vidua // J. Evol. Biol. 15 (1): 134-142.

Garbar A.V., Onishchuk I.P. 2007. The chromosome heteromorfism Octolasium lacteum (Oerley, 1885) (Oligochaeta, Lumbricidae) as result of hibridogenesys. // Rep. Nat. Acad. Sci. Ukraine. 9: 136140. (In Russian).

Garbar. A. V., Vlasenko R. P. 2007. Karyotypes of three species of the genus Aporrectodea (Oligochaeta, Lumbricidae) of the Ukrainian fauna // Comp. Cytogenet. 1(1): 59-62.

Mezhzherin S.V., Vlasenko R.P., Garbar A.V. 2008. Feature of genetic structure of the earthworms complex Aporrectodea (superspecies) caliginosa (Oligochaeta, Lumbricidae) in territory of Ukraine // Cytol. Genet. 42(4): 50-57. (In Russian).

Omodeo P. 1952. Caryology of the Lumbricidae // Caryologia. 4: 173-275.

Omodeo P. 1956. Contributo alla revisione Lumbricidae // Arch. Zool. Italiano. 41: 129-212.

Omodeo P. 1962. Oligochaetes des Alpes // Mem. Mus. Civ. St. Natur. Verona. 10: 71-96.

Peacock F.C., Bunting S.L., Queen K.G. 1965. Serum protein electrophoresis in acrilamyde gel patterns from normal human subjects // Science. 147: $1451-1455$.

Perel T. S. 1979. Range and regularities in the distribution of earthworms of the USSR fauna. Nauka. $272 \mathrm{p}$.

Sitnikova T.J., Ostrovskaja R.M., Poberezhnyj E.S., Kozlova S.A. 1990. New results of researches of 
a polyploidy at Baikal endemic molluscs of genus Benedictia (Gastropoda, Pectinibranchia, Benedictiidae), (p. 266-281) // Linevich A.A., Afanasieva E.L. (Eds). Morphology and evolution of invertebrates. Collected papers. Novosibirsk. 296 p.

Stille B., Ochman H., Selander R.K. 1980. Genetic structure of populations of the earthworm Aporrectodea tuberculata // Oikos. 34: 195-201.

Terhivuo J., Saura A. 1996. Clone pool structure and morphological variation in endogeic and epigeic North-European parthenogenetic earthworm (Oligochaeta: Lumbricidae) // Pedobiologia. 40(3): 226-239.

Vedovini A. 1973. Systematique, caryologie et ecologie des Oligochetes Terrestres de la région Provencale. Nat. Univ. Provence. Marseille. 150 p.
Vlasencko R.P. 2008. Systematics of earthworms of genus Aporrectodea (Oligochaeta, Lumbricidae) faunae of Ukraine: biochemical-genetic, karyological and morphological approaches. Abstract of $\mathrm{PhD}$ thesis. Zhitomir State University, Zhitomir. 24 p. (In Ukrainian).

Vlasenko R.P., Garbar A.V., Mezhzherin S.V. 2007. Clonal structure, karyological and the morphological analysis of the isolated settlement of hipervariable earthworms species Aporrectodea rosea (Oligochaeta: Lumbricidae) // Sci. Bull. Uzhorod Univ. Ser. Biol. 21: 187-191. (In Russian).

Vsevolodova-Perel T. S. 1997. The earthworms in the fauna of Russia. Cadastre and the determiner. Nauka. Moskow. 104 p. (In Russian).

Zrazhevsky A. I. 1957. Earthworms as a factor of fertility of forest soils. Kiev. 273 p. (In Russian ).

Received February 20, 2009.

Accepted by V.V. Golygina, May 25, 2009.

Published December 29, 2009. 